\title{
PERLINDUNGAN KECELAKAAN KERJA YANG TIDAK TERDAFTAR DALAM PROGRAM BADAN PENYELENGGARA JAMINAN SOSIAL (BPJS)
}

\author{
oleh: \\ Rachmat Suharno \\ Fidelis Warso
}

\begin{abstract}
ABSTRAK
Program jaminan sosial bersifat wajib namun masih ada tenaga kerja yang belum terdaftar sebagai peserta sesuai ketentuan yang berlaku yang salah satunya para pekerja harian lepas pada Trans Luxury Hotel Kota Bandung. Sehubungan dengan hal tersebut ada beberapa permasalahan yang menarik untuk dikaji antara lain bagaimanakah bentuk perlindungan yang diberikan terhadap tenaga kerja yang mengalami kecelakaan kerja yang tidak terdaftar dalam program BPJS oleh Trans Luxury Hotel Kota Bandung ? serta apakah faktor-faktor penghambat pemenuhan kewajiban terhadap tenaga kerja yang mengalami kecelakaan kerja yang tidak terdaftar dalam program BPJS oleh Trans Luxury Hotel Kota Bandung ?. Hasil penelitian menyimpulkan bahwa apabila terdapat pekerja yang mengalami kecelakaan kerja namun para pekerja tersebut tidak terdaftar dalam program BPJS yaitu dengan menanggung biaya rumah sakit. Bentuk perlindungan lain bagi tenaga kerja yang belum terdaftar dalam program BPJS yang mengalami kecelakaan kerja yaitu dengan menyediakan medical room dan diberikan pertolongan pertama oleh Tim ERT First Aid, serta adanya pelatihan teknis bagi setiap pekerja baru untuk menyesuaikan lingkungan kerja demi menanggulangi adanya resiko kecelakaan kerja, selain itu juga pekerja diberikan waktu penyesuaian lingkungan kerja dengan alat-alat yang dipergunakan di lingkungan pekerjaan yang belum biasa digunakan. Faktor-faktor penghambat pemenuhan kewajiban terhadap tenaga kerja yang mengalami kecelakaan kerja yang tidak terdaftar dalam program BPJS yaitu antara lain faktor administrasi, faktor pekerja harian lepas yang hanya dikontrak bekerja selama tiga bulan saja, faktor pekerja yang tidak mau mendaftarkan dirinya dalam program BPJS, karena masa kontrak yang hanya tiga bulan saja, dan faktor kurangnya pengetahuan pekerja mengenai BPJS.
\end{abstract}

Kata Kunci: Perlindungan Hukum, Kecelakaan Kerja, BPJS

\section{PENDAHULUAN}

Pembangunan yang dilakukan demi kemajuan Negara Indonesia merupakan pembangunan yang diIakukan secara menyeluruh serta menyentuh segenap aspek hidup masyarakat dalam arti tidak hanya menitikberatkan pada satu bidang tertentu saja. Pembangunan pada bidang ekonomi merupakan penggerak utama membangunan, namun pembangunan ekonomi ini harus disertai upaya saling memperkuat, terkait, serta terpadu dengan pembangunan bidang lainnya termasuk bidang ketenagakerjaan. ${ }^{1}$

Tenaga kerja merupakan faktor penentu bagi mati dan hidupnya suatu bangsa ${ }^{2}$. Pembangunan ketenagakerjaan harus diatur sedemikian rupa sehingga terpenuhi hak-hak dan perlindungan yang mendasar bagi tenaga kerja dan pekerja serta pada saat yang bersamaan dapat mewujudkan kondisi yang kondusif bagi pengembangan dunia usaha. Pembinaan hubungan industrial sebagai bagian dan pembangunan ketenagakerjaan harus diarahkan untuk terus mewujudkan hubungan industrial yang harmonis, dinamis, dan berkeadilan. ${ }^{2}$

\footnotetext{
1) Hernawati RAS dan Dani Durahman, Aspek Hukum dalam Penyelenggaraan Bisnis Perhotelan, Jurnal Ilmiah Universitas Batanghari Jambi, Vol.20 (3), Oktober 2020, hlm. 1033

2) Djumbadi, Hukum Perburuhan, PT. Raja Grafindo Persada, Jakarta, 2004, hlm.1
} 
Tenaga kerja adalah setiap orang yang mampu melakukan pekerjaan guna menghasilkan barang dan/atau jasa baik untuk memenuhi kebutuhan sendiri maupun untuk masyarakat. Ketenagakerjaan adalah segala hal yang berhubungan dengan tenaga kerja pada waktu sebelum, selama, dan sesudah masa kerja. Golongan tenaga kerja adalah setiap orang yang mampu melakukan pekerjaan, baik di dalam maupun di luar hubungan kerja guna menghasilkan jasa atau barang untuk memenuhi kebutuhan masyarakat. Pekerja dalam melakukan hubungan kerja sering diabaikan terkait perlindungannya, sehingga perlindungan terhadap tenaga kerja dimaksudkan untuk melindungi hak-hak dasar pekerja/buruh dan menjamin kesamaan kesempatan serta perlakuan tanpa diskriminasi atas dasar apapun untuk mewujudkan kesejahteraan pekerja/buruh. ${ }^{3}$

Tenaga kerja merupakan faktor penting dalam hal pembangunan industrial, maka kualitas sumber daya manusia perlu diperhatikan dan diberdayakan supaya mereka memiliki nilai lebih dalam arti mampu, lebih terampil, dan lebih berkualitas agar dapat diberdayakan secara optimal dalam pembangunan nasional dan mampu bersaing dalam era globalisasi. Manusia merupakan unsur produksi yang utama, oleh karena itu, kemampuan, keterampilan, dan keahlian manusia perlu terus menerus ditingkatkan melalui perencanaan dan program ketenagakerjaan. Jika manusia mempunyai kemampuan dan kualitas yang tinggi, maka akan mampu mensukseskan pembangunan yang sedang dilaksanakan. Tenaga kerja yang terampil banyak dibutuhkan oleh perusahaan-perusahaan, di mana untuk menjamin kesehatan dan keselamatan tenaga kerja maka perlu dibentuk perlindungan tenaga kerja, karena banyak resiko yang dapat dialami oleh pekerja dalam melakukan pekerjaannya. Apabila sewaktu ketika tenaga kerja mengalami sakit akibat pekerjaannya, kecelakaan kerja maupun hari tua, sudah ada penggantian yang sesuai atas apa yang telah dikerjakannya. ${ }^{4}$

Penyelenggaraan upaya keselamatan dan kesehatan kerja harus dilakukan untuk melindungi keselamatan tenaga kerja guna mewujudkan produktifitas kerja yang optimal. Perlindungan tersebut dilaksanakan sesuai dengan peraturan perundang-undangan yang berlaku. $^{6}$

Hak atas jaminan sosial muncul karena memang sudah kodratnya bahwa manusia memiliki kehidupan yang tidaklah abadi. Seringkali manusia itu tertimpa ketidakberuntungan. Kehidupan manusia dapat diibaratkan seperti magnet yang memiliki dua kutub yaitu kutub utara dan selatan. Dimana hal tersebut sesuai dengan keadaan manusia yang berada dalam ketidakpastian. ${ }^{7)}$

Kecelakaan kerja merupakan resiko yang harus dihadapi oleh tenaga kerja dalam melakukan pekerjaannya. ${ }^{8)}$ Untuk menanggulangi hilangnya sebagian atau seluruh penghasilan yang diakibatkan oleh adanya resiko-resiko sosial seperti sakit atau cacat karena kecelakaan kerja baik fisik maupun mental, maka diperlukan adanya jaminan kecelakaan kerja. Kesehatan dan keselamatan tenaga kerja merupakan tanggung jawab pengusaha sehingga pengusaha memiliki kewajiban untuk membayar iuran jaminan kecelakaan kerja yang berkisar antara $0,24 \% \mathrm{~s} / \mathrm{d} 1,74 \%$ sesuai kelompok jenis usaha. ${ }^{9}{ }^{9}$

\footnotetext{
3) Gunawi Karta Sapoetra, Hukum Perburuhan Pancasila Bidang Pelaksanaan Hubungan Kerja, Armico, Bandung, 1993, hlm.1

4) Zainal Asikin, dkk, Dasar-Dasar Hukum Perburuhan, Cet 4, Raja Grafindo Persada,Jakarta, 2002, hlm.76.

6) Lalu Husni, Pengantar Hukum Ketenagakerjaan, Edisi Revisi, Raja Grafindo Persada, Jakarta, 2014, hlm.133. 2008, hlm.2.

7) Zaeni Asyhadie, Aspek-aspek Hukum Jaminan Sosial Tenaga Kerja, Cet.1, PT.Rajawali, Jakarta,

8) Tim Visi Yustisia, Memperoleh Jaminan Sosial Dari BPJS, cet.1, Transmedia Pustaka, Jakarta, 2014, hlm.8.

9) ibid, hlm.8.
} 
Penyelenggaraan program jaminan sosial merupakan salah satu tanggung jawab dan kewajiban Negara untuk memberikan perlindungan sosial ekonomi kepada masyarakat. Sesuai dengan kondisi kemampuan keuangan negara Indonesia seperti halnya berbagai negara berkembang lainnya, mengembangkan program jaminan sosial berdasarkan finded social security, yaitu jaminan sosial yang didanai oleh peserta dan masih terbatas pada masyarakat pekerja di sektor formal. Negara membentuk suatu program jaminan sosial yaitu, program Jaminan Sosial Tenaga Kerja yang bergerak secara khusus mengatur jaminan sosial bagi tenaga kerja swasta meliputi jaminan kecelakaan kerja, jaminan kematian, jaminan hari tua, dan jaminan pemeliharaan kesehatan. ${ }^{10)}$

Badan Penyelenggara Jaminan Sosial (yang selanjutnya disebut BPJS) merupakan badan hukum yang dibentuk untuk menyelenggarakan program jaminan sosial sebagai salah satu bentuk perlindungan sosial untuk menjamin seluruh rakyat agar dapat memenuhi kebutuhan dasar hidupnya yang layak. BPJS merupakan transformasi dari Jaminan Sosial Tenaga Kerja (JAMSOSTEK) yang berdiri pada tahun 1992. BPJS sebagaimana dimaksud yaitu BPJS Kesehatan dan BPJS Ketenagakerjaan. BPJS Ketenagakerjaan suatu program jaminan sosial bagi tenaga kerja bersifat wajib yang menyelenggarakan program Jaminan Kecelakaan Kerja (JKK), Jaminan Hari Tua (JHT), Jaminan Pensiun (JP) dan Jaminan Kematian (JKM). ${ }^{11)}$

Pasal 8 ayat (3) Peraturan Pemerintah Nomor 44 Tahun 2015 Tentang Penyelenggaraan Program Jaminan Kecelakaan Kerja Dan Jaminan Kematian menegaskan bahwa dalam hal pemberi kerja belum melaporkan dan membayar iuran maka bila terjadi risiko terhadap pekerjanya, pemberi kerja wajib memberikan hak-hak pekerja sesuai dengan ketentuan. Pasal 2 ayat (1) Peraturan Presiden Republik Indonesia Nomor 109 Tahun 2013 Tentang Penahapan Kepesertaan Program Jaminan Sosial menegaskan bahwa setiap pemberi kerja dan pekerja berhak atas jaminan sosial, peserta program jaminan sosial itu sendiri terdiri atas peserta penerima upah dan peserta bukan penerima upah. Jaminan sosial dimaksudkan untuk memberikan perlindungan bagi tenaga kerja terhadap resiko sosial-ekonomi yang menimpa tenaga kerja dalam melakukan pekerjaan baik berupa kecelakaan kerja, sakit, hari tua maupun meninggal dunia, dengan demikian diharapkan ketenangan bagi pekerja akan terwujud, sehingga produktifitas akan semakin meningkat. Dalam prakteknya meski program jaminan sosial telah dirancang sejak tahun 1992, tenyata masih ada pekerja/buruh yang belum terdaftar sebagai peserta program ini sesuai ketentuan yang berlaku yang salah satunya terdapat pada Trans Luxury Hotel Kota Bandung.

Berdasarkan latar belakang tersebut di atas, penulis mengindentifikasikan permasalahan sebagai berikut :

1. Bagaimanakah bentuk perlindungan yang diberikan oleh Trans Luxury Hotel Kota Bandung terhadap tenaga kerja yang mengalami kecelakaan kerja yang tidak terdaftar dalam program BPJS ?

2. Apakah faktor-faktor penghambat pemenuhan kewajiban Trans Luxury Hotel Kota Bandung terhadap tenaga kerja yang mengalami kecelakaan kerja yang tidak terdaftar dalam program BPJS ?

\section{TINJAUAN TEORITIS}

Perlindungan tenaga kerja merupakan faktor utama dalam kesehatan dan keselamatan kerja. Perlindungan tenaga kerja, terlebih dalam bentuk peraturan perundang-undangan berkembang sangat lambat. Pertentangan terjadi antara serikat-serikat tenaga kerja dan para reformis, di dalam maupun di luar parlemen, dengan para pengusaha besar dan kaum intelektual pengusung doktrin Laissez Faire. Upaya nyata dimulai pada tahun 1818 oleh

\footnotetext{
10) Sulastomo, Sistem Jaminan Sosial Nasional, PT. Raja Grafindo Persada, Jakarta, 2008, hlm.41.
}

11) ibid, hlm.5. 
Robert Owen, pengusaha terbesar dan terkaya sektor penenunan katun serta penggagas Sosialisme Inggris, melalui kampanyenya tentang penghapusan eksploitasi tenaga kerja, terutama tenaga kerja anak di Inggris. Terhadap kondisi perburuhan yang demikian maka hukum berperan besar melalui penetapan aturan-aturan yang bertujuan melindungi tenaga kerja terhadap resiko-resiko yang mungkin timbul dalam pelaksanaan pekerjaan mereka. ${ }^{12)}$

Kesehatan dan keselamatan kerja diperlukan seiring dengan perkembangan industri yang membawa serta penggunaan berbagai alat, mesin instalasi dan bahan-bahan berbahaya maupun beracun. Penggunaan alat dan bahan yang awalnya bertujuan untuk memudahkan pekerja/buruh dalam melakukan pekerjaannya kerap justru menimbulkan peningkatan risiko kerja dalam proses penggunaan/pengerjaannya. Resiko yang langsung berakibat bagi pekerja/buruh umumnya adalah risiko kecelakaan kerja dan penyakit akibat kerja, yang pada tingkat tertentu dapat menyebabkan putusnya hubungan kerja sehingga kelangsungan pekerjaan/penghidupan pekerja/buruh dan keluarganya tidak lagi dapat dipertahankan. Di sisi lain, terdapat resiko bagi pengusaha berupa kemungkinan terjadinya berbagai kerusakan di lingkungan kerja dalam kaitannya dengan kelangsungan aset dan alat-bahan produksi serta timbulnya biaya-biaya kompensasi. ${ }^{13)}$

Hubungan antara perlunya kesehatan dan keselamatan kerja diterapkan dengan kerugian sebagai konsekuensi dari dampak yang terjadi dan dibahas dalam beberapa teori. Teori domino kecelakaan kerja mengulas bahwa setiap kecelakaan yang menimbulkan cedera mencakup 5 (lima) faktor berurutan yang digambarkan sebagai lima domino dalam posisi sejajar, yaitu : ${ }^{14)}$
1. Kebiasaan.
2. Kesalahan orang.
3. Perbuatan dan kondisi tidak aman (hazard).
4. Kecelakaan.
5. Cedera.

Setiap negara pada hakekatnya pasti memberikan suatu perlindungan hukum bagi setiap warga negaranya. Di dalam UUD 1945 alenia ke-4 disebutkan bahwa "Pemerintah negara Indonesia melindungi segenap bangsa Indonesia dan seluruh tumpah darah Indonesia dan untuk memajukan kesejahteraan umum....". Ini menunjukan bahwa pemerintah memberikan perlindungan bagi seluruh rakyat Indonesia, termasuk para pekerja dan buruh. Perlindungan tenaga kerja bertujuan untuk menjamin berlangsungnya sistem hubungan kerja secara harmonis tanpa disertai adanya tekanan dari pihak yang kuat kepada pihak yang lemah. Tenaga kerja adalah setiap orang yang mampu melakukan pekerjaan guna menghasilkan barang atau jasa baik untuk memenuhi kebutuhan sendiri maupun untuk masyarakat. ${ }^{15}$ )

Ada dua macam perlindungan hukum, yaitu : ${ }^{16)}$

1. Perlindungan hukum preventif.

Preventif artinya rakyat diberikan kesempatan untuk mengajukan keberatan (inspraak) atau pendapatnya sebelum keputusan pemerintah mendapat bentuk yang definitif. Dalam hal ini artinya perlindungan hukum yang preventif ini bertujuan untuk mencegah terjadinya sengketa.

\footnotetext{
103-104.

12) Aloysius Uwiyono, dkk., Asas-asas Hukum Perburuhan, Cet. 1, Rajawali Pers, Jakarta, 2014, hlm.

13) Rudi Suardi, Sistem Manajemen Keselamatan dan Kesehatan Kerja, PPM, Jakarta, 2007, hlm. 4-5.

14) ibid, hlm. 4-5.

15) Hardijan Rusli, Hukum Ketenagakerjaan, Ghalian Indonesia, Jakarta, 2003, hlm.12.

16) Philipus M.Hadjon, Perlindungan Hukum Bagi Rakyat Indonesia, Bina Ilmu Surabaya, 1987, hlm.1.
} 
2. Perlindungan hukum represif.

Perlindungan hukum represif, yaitu perlindungan hukum yang diberikan setelah adanya sengketa. Perlindungan hukum represif ini bertujuan untuk menyelesaikan sengketa.

Perlindungan terhadap tenaga kerja dibagi menjadi tiga macam yaitu :17)

1. Perlindungan sosial, yaitu perlindungan yang berkaitan dengan usaha kemasyarakatan yang tujuannya untuk memungkinkan pekerja mengenyam dan khususnya sebagai anggota masyarakat dan anggota keluarga. Perlindungan sosial ini disebut juga dengan kesehatan kerja.

2. Perlindungan teknis, yaitu suatu perlindungan yang berkaitan dengan usaha-usaha untuk menjaga pekerja terhindar dari bahaya kecelakaan saat bekerja. Perlindungan ini disebut sebagai keselamatan kerja.

3. Perlindungan ekonomis, yaitu suatu perlindungan yang berkaitan dengan usahausaha untuk memberikan kepada pekerja suatu penghasilan yang cukup guna memenuhi kebutuhan sehari-hari.

Bentuk perlindungan hukum dalam hukum ketenagakerjaan yang diberikan berupa perlindungan hukum di bidang keamanan kerja di mana baik dalam waktu yang relatif singkat atau lama akan aman dan ada jaminan keselamatan bagi pekerja. Dengan adanya perlindungan hukum terhadap pekerja, negara mewajibkan kepada pengusaha untuk menyediakan alat keamanan kerja bagi pekerja. Dalam hal pertanggungjawaban terhadap pekerja apabila terjadi kecelakaan kerja ketika melaksanakan kewajibannya dalam pekerjaan, maka pengusaha akan menanggung beban yang timbul secara materiil dengan memberikan penggantian dari biaya yang timbul akibat kecelakaan kerja. ${ }^{18)}$

Perlindungan pekerja dapat dilakukan, baik dengan jalan memberikan tuntunan, maupun dengan jalan meningkatkan pengakuan hak-hak asasi manusia, perlindungan fisik dan teknis serta sosial dan ekonomi melalui norma yang berlaku dalam lingkungan kerja itu. Dengan demikian maka perlindungan kerja ini akan mencangkup :19)

1. Norma keselamatan kerja yang meliputi keselamatan kerja, keadaan tempat kerja dan lingkungan serta cara-cara melakukan pekerjaan.

2. Norma kesehatan kerja dan heigiene kesehatan perusahaan yang meliputi pemeliharaan dan mempertinggi derajat kesehatan pekerja, perawatan tenaga kerja yang sakit.

3. Norma kerja yang meliputi perlindungan terhadap tenaga kerja yang berkaitan dengan waktu bekerja, sistem pengupahan, istirahat, cuti.

4. Kepada tenaga kerja yang mendapat kecelakaan akibat pekerjaan, berhak atas ganti rugi perawatan dan rehabilitasi akibat kecelakaan.

\section{PEMBAHASAN}

Perlindungan yang diberikan manajemen Trans Luxury Hotel Kota Bandung bagi para tenaga kerjanya mengikuti peraturan perundang-undangan yang berlaku yaitu UndangUndang Nomor 13 Tahun 2003 Tentang Ketenagakerjaan dan sesuai dengan perjanjian kerja antara manajemen Trans Luxury Hotel Kota Bandung dan pekerja, dimana manajemen Trans Luxury Hotel Kota Bandung memberikan perlindungan sesuai dengan hak-hak pekerja. manajemen Trans Luxury Hotel Kota Bandung telah mendaftarkan seluruh pekerja tetap

17) Zaeni Asyhadie, Hukum Kerja (Hukum Ketenagakerjaan Bidang Hubungan Kerja), edisi revisi 2, PT.Raja Grafindo Persada, Jakarta, 2008, hlm.20.

18) Soedarjadi, Hukum Ketenagakerjaan di Indonesia, Pustaka Yustisia, Yogyakarta, 2008, hlm.53.

19) Zainal Asikin, op.cit., hlm.96. 
dalam program pemerintah baik BPJS Kesehatan dan BPJS Ketenagakerjaan. Apabila ada ketentuan antara manajemen Trans Luxury Hotel Kota Bandung dengan pekerja di luar perundang-undangan seperti masih adanya tenaga kerja yang belum terdaftar dalam program BPJS maka sebelumnya sudah ada perjanjian kerja antara manajemen Trans Luxury Hotel Kota Bandung dengan pekerja, manajemen Trans Luxury Hotel Kota Bandung tetap akan memberikan perlindungan serta hak-hak pekerja sesuai dengan ketentuan yang berlaku.

Kecelakaan yang terjadi dalam hubungan kerja termasuk sakit yang diakibatkan karena kerja, kecelakaan kerja merupakan resiko yang sering kali dihadapi oleh tenaga kerja yang dihadapi para pekerjanya untuk menanggulangi hilangnya sebagian atau seluruh penghasilan yang diakibatkan oleh adanya risiko sosial, seperti kematian atau karena kecelakaan kerja, baik fisik maupun mental diperlukan adanya jaminan kecelakaan kerja. kesehatan dan keselamatan tenaga kerja merupakan tanggung jawab pengusaha, sehingga pengusaha memiliki kewajiban untuk membayar iuran jaminan kecelakaan kerja, jaminan kecelakaan kerja betujuan untuk melindungi pekerja/buruh dan keluarganya dari kecelakaan yang berhubungan dengan pekerjaan pemberian santunan meliputi kecelakaan di tempat kerja, kecelakaan menuju di tempat kerja, atau pulang dari tempat kerja, di tempat lain yang berhubungan dengan pekerjaan dalam rangka tugas kerja dan sakit di tempat kerja.

Bentuk pertanggungjawaban manajemen Trans Luxury Hotel Kota Bandung, apabila terdapat pekerja yang mengalami kecelakaan kerja namun para pekerja tersebut tidak terdaftar dalam program BPJS yaitu dengan menanggung biaya rumah sakit. Bentuk perlindungan lain yang disediakan oleh manajemen Trans Luxury Hotel Kota Bandung dalam rangka perlindungan bagi tenaga kerja yang belum terdaftar dalam program BPJS yang bekerja di Trans Luxury Hotel Kota Bandung sebelum terjadinya kecelakaan kerja yaitu dengan medical room dan diberikan pertolongan pertama oleh Tim ERT First Aid Trans Luxury Hotel Bandung, serta adanya pelatihan teknis bagi setiap pekerja baru untuk menyesuaikan lingkungan kerja demi menanggulangi adanya resiko kecelakaan kerja, selain itu juga pekerja diberikan waktu penyesuaian lingkungan kerja dengan alat-alat yang dipergunakan di hotel yang belum biasa digunakan.

Metode pertanggungjawaban manajemen Trans Luxury Hotel Kota Bandung tersebut maksudnya adalah membebankan tanggung jawab untuk menanggung tenaga kerja yang terkena resiko kerja, sepenuhnya pada manajemen Trans Luxury Hotel Kota Bandung. Metode ini didasarkan pada prinsip, bahwa siapa yang mempekerjakan tenaga kerja tentu harus bertanggung jawab atas tenaga kerja tersebut.

Ketentuan-ketentuan mengenai kewajiban mendaftarkan BPJS para tenaga kerja oleh perusahaan telah tegas terdapat dalam Undang-Undang Nomor 24 Tahun 2011 Tentang Badan Penyelenggara Jaminan Sosial dan Keputusan Menteri Tenaga Kerja Dan Transmigrasi Nomor KEP-100/MEN/VI/2004 Tentang Ketentuan Pelaksanaan Perjanjian Kerja Waktu Tertentu untuk tenaga kerja harian lepas, kontrak, atau outsorcing. Namun masih terdapat perusahaan-perusahaan, salah satunya adalah Trans Luxury Hotel Kota Bandung, yang tidak mendaftarkan pekerja nya dalam program BPJS. Hal tersebut terjadi karena beberapa faktor, antara lain :

1. Faktor administrasif, faktor ini antara lain terjadi karena persyaratan administratif yang sangat ketat yang disyaratkan oleh BPJS untuk pendaftaran program BPJS, proses administrasi yang terlalu panjang dan proses birokrasi serta tertib admnistrasi yang sangat ketat sehingga menyebabkan para tenaga kerja dengan Pelaksanaan Perjanjian Kerja Waktu Tertentu atau pekerja daily worker/pekerja harian lepas enggan dan malas untuk mendaftarkan diri pada program BPJS. Proses administrasi yang terlalu panjang dan proses birokrasi serta tertib admnistrasi yang sangat ketat yang dilaksanakan oleh BPJS sesuai dengan bunyi Pasal 16 ayat (2) Undang-Undang Nomor 24 Tahun 2011 Tentang Badan 
Penyelenggara Jaminan Sosial yang menyebutkan setiap orang sebagaimana dimaksud pada ayat (1) wajib memberikan data mengenai dirinya dan anggota keluarganya secara lengkap dan benar kepada BPJS, namun hal ini oleh sebagian pekerja dirasakan sangat berat untuk memenuhinya.

2. Faktor pekerja daily worker/pekerja harian lepas yang hanya dikontrak bekerja selama tiga bulan saja, dan belum tentu masa kontrak tersebut diperpanjang. Hal ini yang menyebabkan pekerja daily worker/pekerja harian lepas tidak mendaftarkan diri sebagai peserta dalam program BPJS, karena berdasarkan Pasal 19 ayat (1) Undang-Undang Nomor 24 Tahun 2011 Tentang Badan Penyelenggara Jaminan Sosial, pemberi kerja wajib memungut iuran yang menjadi beban peserta dari pekerjanya dan menyetorkannya kepada BPJS, walaupun iurannya terhitung kecil namun hal ini menjadi alasan bagi pekerja daily worker/pekerja harian lepas untuk tidak mendaftarkan diri sebagai peserta program BPJS karena para pekerja daily worker/pekerja harian lepas hanya dikontrak bekerja selama tiga bulan saja, dan belum tentu masa kontrak tersebut diperpanjang.

3. Faktor kurangnya pengetahuan pekerja mengenai BPJS. Sosialisasi mengenai pentingnya BPJS harus gencar dilakukan baik itu oleh pemerintah ataupun perusahaan-perusahaan, hal ini penting dilakukan agar para pekerja mengetahui secara mendalam mengenai pentingnya mendaftarkan diri dalam program kepersertaan BPJS. Selain BPJS menjamin masa depan pekerja BPJS juga memiliki manfaat lain yang bisa didapatkan dengan menjadi peserta BPJS Ketenagakerjaan.

Upaya yang dapat dilakukan dalam menghadapi hambatan pendaftaran pekerja dalam program BPJS yaitu :

1. Mengutamakan pekerja yang memiliki data administrasi atau KTP yang lengkap dan masih berlaku, karena KTP merupakan salah satu syarat dalam pendaftaran BPJS. Maka setiap pekerja harus membawa KTP yang masih berlaku terlebih dahulu sebelum bekerja pada perusahaan.

2. Adanya perjanjian, yaitu ketentuan mengenai tiga bulan masa kontrak kerja tersebut. Perjanjian dibuat dengan jelas mengenai hak dan kewajiban masing-masing pihak, dalam perjanjian tersebut tentunya juga mengutamakan bentuk perlindungan bagi tenaga kerja daily worker.

3. Memberikan sosialisasi kepada seluruh pekerja mengenai resiko kecelakaan kerja dan kewajiban mendaftar pada program BPJS meskipun kontrak kerja yang hanya tiga bulan.

4. Memberikan sosialisasi bagi pekerja yang baru bekerja pada perusahaan tentang bentuk jaminan sosial yang diselenggarakan Pemerintah yaitu BPJS.

Upaya yang diberikan Trans Luxury Hotel Kota Bandung sampai saat ini bagi tenaga kerja yang tidak terdaftar dalam program BPJS yaitu dengan adanya penyesuaian lingkungan kerja terlebih dahulu, kemudian dengan adanya medical room dan diberikan pertolongan pertama oleh Tim ERT First Aid Trans Luxury Hotel Bandung, maka apabila terjadi kecelakaan terhadap para pekerja yang tidak terdaftar dalam program BPJS, pihak Trans Luxury Hotel Kota Bandung dapat bertanggung jawab terhadap kecelakaan tersebut.

Dalam melaksanakan perlindungan terhadap tenaga kerja harus diusahakan adanya perlindungan dan perawatan yang layak bagi semua tenaga kerja dalam melakukan pekerjaannya sehari-hari, terutama dalam bidang keselamatan kerja serta menyangkut normanorma perlindungan tenaga kerja. Tujuan perlindungan tenaga kerja adalah untuk menjamin berlangsungnya sistem hubungan kerja secara harmonis tanpa disertai adanya tekanan dari 
pihak yang kuat kepada pihak yang lemah, pengusaha wajib melaksanakan ketentuan perlindungan tenaga kerja sesuai peraturan perundang-undangan yang berlaku.

Pengawasan terhadap perusahaan oleh pemerintah dalam program Jaminan Sosial merupakan hal yang penting untuk memastikan perlindungan hukum terhadap tenaga kerja di bawah naungan Perusahaan. Tujuan dari pengawasan itu adalah agar dapat memantau pelaksanaan Undang-Undang Nomor 24 Tahun 2011 Tentang Badan Penyelenggara Jaminan Sosial, sehingga undang-undang tersebut berjalan lebih efektif. Sanksi yang diberikan kepada Perusahaan merupakan upaya penegakan hukum oleh Pemerintah terkait dengan upaya memberikan perlindungan hukum kepada masyarakat terutama pekerja di lingkungan perusahaan yang banyak pekerja harian lepas atau kontrak.

Penegakan hukum ini termasuk dalam ranah hukum perdata berkaitan erat dengan ganti kerugian. Sanksi perdata yang berkaitan dengan perusahaan adalah ganti rugi atas kerugian atau kerusakan yang telah ditimbulkan. Selain sanksi tersebut, penegakan hukum yang dilakukan oleh pemerintah dalam rangka perlindungan jaminan sosial tenaga kerja berhubungan dengan pemberian sanksi administratif yaitu tidak mendapatkan layanan publik. Sedangkan mengenai sanksi administrasi diatur tersendiri melalui Peraturan Pemerintah Nomor 86 Tahun 2013 tentang Tata Cara Pengenaan Sanksi Administrasi Kepada Pemberi Kerja selain Penyelenggara Negara, hukum harus dilaksanakan dan ditegakkan. Hukum itu harus berlaku, dan dilaksanakan dengan cara tidak boleh menyimpang. Dengan cara demikian, maka ada kepastian hukum dan kepastian hukum akan menciptakan tertib masyarakat.

\section{KESIMPULAN DAN SARAN}

Bentuk perlindungan terhadap pekerja yang mengalami kecelakaan kerja namun para pekerja tersebut tidak terdaftar dalam program BPJS yaitu dengan menanggung biaya rumah sakit para pekerja yang mengalami kecelakaan kerja namun para pekerja tersebut tidak terdaftar dalam program BPJS. Bentuk perlindungan lain dalam rangka perlindungan bagi tenaga kerja yang belum terdaftar dalam program BPJS sebelum terjadinya kecelakaan kerja yaitu dengan dibuatnya ruang pertolongan pertama bagi para pekerja yang mengalami kecelakaan kerja dan diberikan pertolongan pertama oleh tim dari perusahaan tersebut oleh karena itu terhadap karyawan tetap dari perusahaan tersebut harus ada beberapa karyawan yang mendapat pelatihan dalam rangka memberikan pertolongan pertama, serta adanya pelatihan teknis bagi setiap pekerja baru untuk menyesuaikan lingkungan kerja demi menanggulangi adanya resiko kecelakaan kerja, selain itu juga pekerja diberikan waktu penyesuaian lingkungan kerja dengan alat-alat yang dipergunakan di perusahaan yang belum biasa digunakan. Faktor-faktor penghambat pemenuhan kewajiban terhadap tenaga kerja yang mengalami kecelakaan kerja yang tidak terdaftar dalam program BPJS, yaitu antara lain faktor administrasif, faktor pekerja daily worker/pekerja harian lepas yang hanya dikontrak bekerja selama tiga bulan saja, dan belum tentu masa kontrak tersebut diperpanjang, serta faktor kurangnya pengetahuan pekerja mengenai BPJS.

Bentuk pertanggungjawaban dari perusahaan apabila terdapat pekerjanya yang mengalami kecelakaan kerja dan pekerja tersebut belum terdaftar dalam program BPJS maka perusahaan wajib untuk menanggung biaya rumah sakit, namun sebaiknya untuk para tenaga kerja yang tergabung di sebuah perusahaan walaupun hanya sebagai pekerja harian lepas tetap didaftarkan keikutsertaannya dalam program BPJS, hal ini agar sesuai dengan peraturan yang berlaku. Dilihat dari faktor penghambat pemenuhan kewajiban terhadap tenaga kerja yang mengalami kecelakaan kerja yang tidak terdaftar dalam program BPJS, maka dari itu harus ditinjau ulang terhadap syarat-syarat pemenuhan untuk dapat ikut serta dalam program BPJS, selain itu sosialisasi mengenai pentingnya program BPJS harus gencar dilakukan oleh pemerintah. Atau perusahaan dapat mendaftarkan para pekerja harian lepas ke perusahaan asuransi swasta, dengan sistem premi asuransi bulanan sesuai dengan waktu kontrak para 
pekerja harian lepas tersebut. Perlu dilakukan suatu pencegahan kecelakaan yang mungkin terjadi serta penanganan dan penanggulangan yang sesuai dengan kebutuhan pekerja agar kecelakaan dan penyakit akibat kerja dapat dicegah dan ditangani sedini mungkin, seefektif mungkin dan seefisien mungkin. Sehingga dapat berguna bagi manajemen hotel dalam menerapkan standarisasi kesehatan dan pencegahan kecelakaan akibat kerja. Apabila semua standar tersebut dapat diterapkan secara baik dan benar, maka karyawan akan merasa aman dan semangat dalam menjalankan pekerjaan.

\section{DAFTAR PUSTAKA}

Aloysius Uwiyono, dkk., Asas-asas Hukum Perburuhan, Cet. 1, Rajawali Pers, Jakarta, 2014. Djumbadi, Hukum Perburuhan, PT. Raja Grafindo Persada, Jakarta, 2004.

Gunawi Karta Sapoetra, Hukum Perburuhan Pancasila Bidang Pelaksanaan Hubungan Kerja, Armico, Bandung, 1993.

Hardijan Rusli, Hukum Ketenagakerjaan, Ghalian Indonesia, Jakarta, 2003.

Lalu Husni, Pengantar Hukum Ketenagakerjaan, Edisi Revisi, Raja Grafindo Persada, Jakarta, 2014.

Philipus M.Hadjon, Perlindungan Hukum Bagi Rakyat Indonesia, Bina Ilmu Surabaya, 1987.

Rudi Suardi, Sistem Manajemen Keselamatan dan Kesehatan Kerja, PPM, Jakarta, 2007.

Soedarjadi, Hukum Ketenagakerjaan di Indonesia, Pustaka Yustisia, Yogyakarta, 2008.

Sulastomo, Sistem Jaminan Sosial Nasional, PT. Raja Grafindo Persada, Jakarta, 2008.

Tim Visi Yustisia, Memperoleh Jaminan Sosial Dari BPJS, cet.1, Transmedia Pustaka, Jakarta, 2014.

Yusuf Subkhi, Perlindungan Tenaga Kerja, Rajawali Pers, Jakarta, 2002.

Zainal Asikin, dkk, Dasar-Dasar Hukum Perburuhan, Cet 4, Raja Grafindo Persada,Jakarta, 2002 .

Zaeni Asyhadie, Aspek-aspek Hukum Jaminan Sosial Tenaga Kerja, Cet.1, PT.Rajawali, Jakarta, 2008.

Zaeni Asyhadie, Hukum Kerja (Hukum Ketenagakerjaan Bidang Hubungan Kerja), edisi revisi 2, PT.Raja Grafindo Persada, Jakarta, 2008. 